\title{
Antarctic Ice Sheet and climate history since the Last Glacial Maximum
}

Michael J. Bentley ${ }^{1,2}$ and Dominic A. Hodgson ${ }^{2}$

'Department of Geography, University of Durham, UK; m.j.bentley@durham.ac.uk; ²British Antarctic Survey, Cambridge, UK

Reconstructing the former dimensions and deglacial history of the Antarctic Ice Sheet (Fig. 1) along with Antarctic paleoclimate is important for understanding forcing mechanisms of ice sheet change. Here, we review briefly a number of recent research highlights that have advanced our understanding of the retreat history of the ice sheet and the changes in paleoclimate since the LGM.

\section{Ice sheet history}

The configuration of the Antarctic ice sheet at the Last Glacial Maximum (LGM) is now much better known than a decade ago, largely due to the use of swath bathymetric surveying techniques on the continental shelf (Fig. 2). Detailed surveys have mapped grounding-zone wedges and similar features marking the maximum position and retreat history of the ice sheet (Fig. 2) in areas such as the Antarctic Peninsula (Anderson, 1999; Canals et al., 2000; Ó Cofaigh et al., 2008), Pine Island Bay (Lowe and Anderson, 2002), Ross Sea, sub-Antarctic islands (Graham et al., 2008), Prydz Bay, and some other areas of the East Antarctic margin. Onshore glacial geomorphological studies have identified the maximum elevation of the ice sheet where it intersects interior nunataks (ice free mountain peaks or ridges surrounded by ice sheets or glaciers), and these limits have been dated using cosmogenic isotopes (Stone et al., 2003; Bentley et al., 2006; Mackintosh et al., 2007).Marine geophysical and geological studies have inferred the retreat history of the ice sheet across the continental shelf. For example, Heroy and Anderson (2007) showed that initial retreat of the Antarctic Peninsula Ice Sheet began from the outer continental shelf at $\sim 18 \mathrm{kyr}$, reaching the middle shelf several thousand years later. They suggested that retreat began first in the north and progressively later in the southern Antarctic Peninsula but that by the time the grounding line had reached the inner shelf, different basins were responding in different ways, probably due to different topographic configurations.

Similarly, the onshore studies using exposure dating have shown different behavior in different sectors of the ice sheet. Stone et al. (2003) demonstrated continuous thinning of the West Antarctic Ice Sheet in the eastern Ross Sea for at least the last $10 \mathrm{kyr}$ and continuing today, whereas on the Antarctic Peninsula Bentley et al. (2006) showed that the ice thinned and retreated close to its present limits by $9.6 \mathrm{kyr}$. A similar result was noted for the Framnes Mountains in East Antarctica, where the ice was close to its present elevation by $6 \mathrm{kyr}$ (Mackintosh et al., 2007).

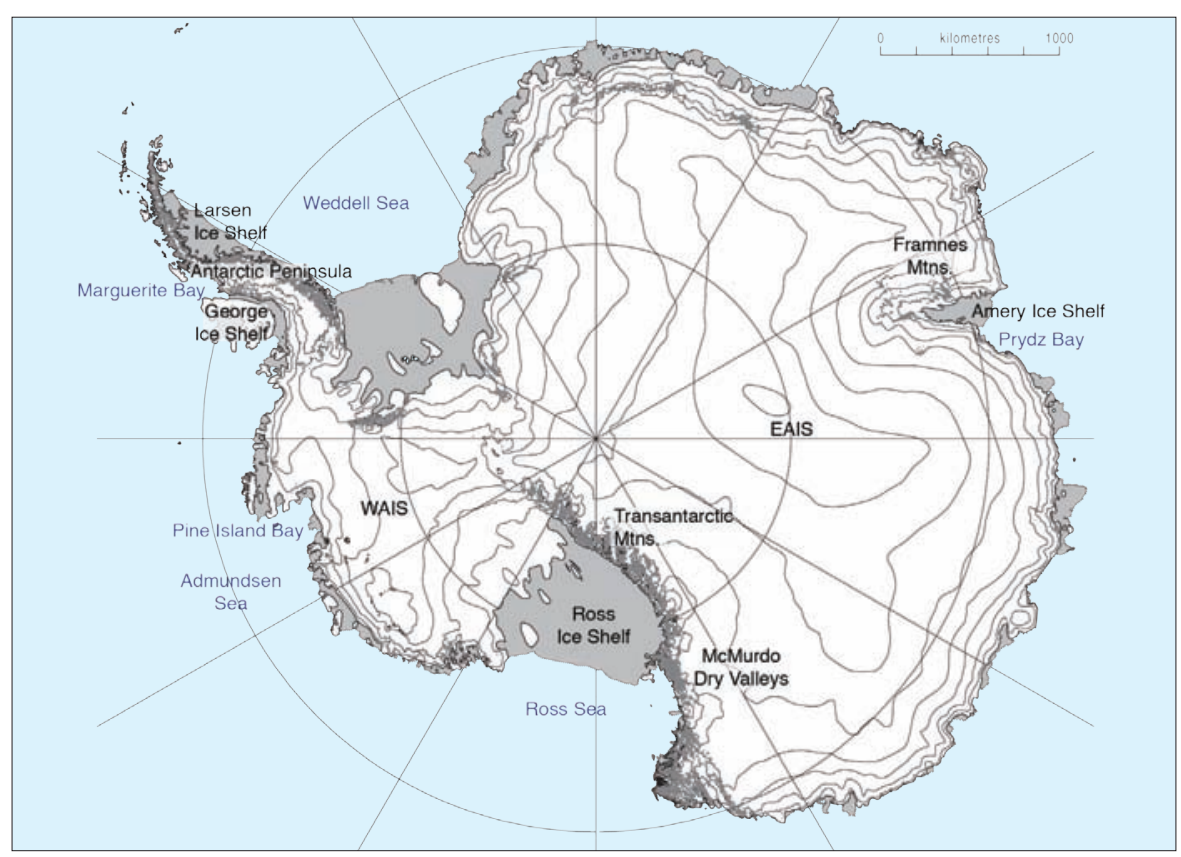

Figure 1: Map of Antarctica showing locations mentioned in the text

There have been other approaches to determining the deglacial history of the ice sheet. Dating of organic remains (shells, penguin bones, guano, sealskin) in raised beaches and of sediment cores from isolation basins (marine inlets now uplifted to form freshwater lakes) has been used to establish relative sea level curves to provide independent constraints on ice sheet volume and deglacial history (e.g., Hall et al., 2004; Bassett et al., 2007). New biological constraints on ice sheet history are also emerging from genetic studies of faunal communities on nunataks and ice-free coastal regions that have apparently been present since before the LGM, requiring the presence of ice-free areas at both high and low elevation even at peak glaciation (Convey et al., 2008; see also Newman et al., this issue).

Long-term ice shelf history has been used to place recent ice shelf collapses in context and a number of groups have used paleo-records to identify past (in)stability of Holocene ice shelves, including early Holocene collapse of the George VI Ice Shelf, mid-Holocene collapse of the Larsen-A/Prince Gustav Channel ice shelf complex, and apparent stability of LarsenB since the LGM (see Hodgson et al., 2006 for review), as well as a major retreat of the Amery lce Shelf to at least $80 \mathrm{~km}$ landward of its present location during the mid-Holocene climatic optimum (Hemer and Harris, 2003).

\section{Antarctic paleoclimate}

Antarctic paleoclimate records come primarily from proxies in ice cores or marine

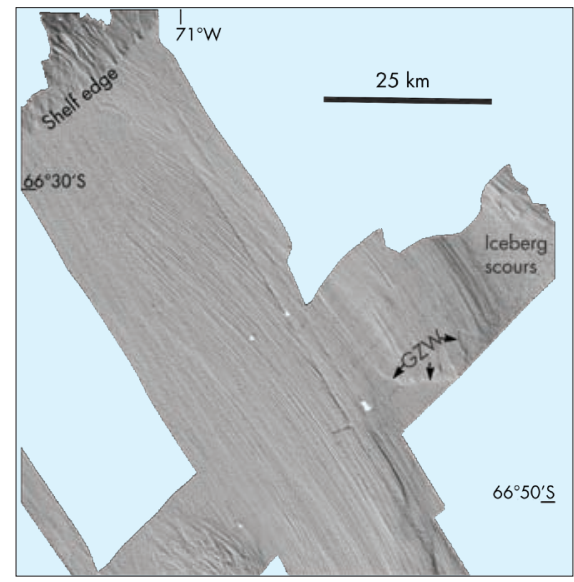

Figure 2: Shaded relief image of mega-scale glacial lineations produced beneath the Marguerite Trough ice stream, Antarctic Peninsula continental shelf. The lineations are formed in soft sediment in water depths of 500-700 m. They extend to the shelf edge, beyond which a well-developed series of gullies are incised into the upper continental slope. The lineations are replaced in shallower water by iceberg plough-marks. The position of a prominent sediment scarp formed in till, which marks a former grounding-zone position of the ice stream, is also indicated (GZW). The data were collected using a multibeam (swath) echo sounder. Grid cell size in the image is $50 \times 50 \mathrm{~m}$ (Modified from Ó Cofaigh et al., 2008). 
and lake sediment cores. The'paleoclimate' information contained in each of these records is often very different. Ice cores contain a mixture of global signals (e.g., concentrations of $\mathrm{CO}_{2}$ and $\mathrm{CH}_{4}$ ); regional signals (e.g., average sea-ice extent from sea salts and methanesulfonic acid), and local signals (e.g., precipitation/snow accumulation rate). Lake sediment cores record some global phenomena (e.g., long range transport of pollutants) but more commonly are used to identify regional signals such as temperature and relative sea level change, and local changes such as the advance and retreat of catchment glaciers and ice shelves. Marine sediment cores are similarly versatile, providing information on major oceanographic changes such as changes in currents or distribution of water masses, regional changes in parameters such as sea-ice extent and surface water productivity, and local changes such as the extent of ice shelves and glaciers.

Collectively these records offer a great wealth of information but also present a similarly great challenge for those attempting to assimilate the data into meaningful syntheses or identify mechanisms of change at a resolution that is of use for understanding climate forcing and constraining future climate scenarios. Following a workshop in Cambridge, one group recently attempted a synthesis of paleoclimate datasets across disciplines focusing on the Antarctic Peninsula region (Bentley et al., in press). The aim was to identify Holocene warm periods and to determine the underlying mechanisms causing them. Results showed that there are two warm periods recorded in most of the proxy records-a period of early Holocene warmth, and a Mid-Holocene Hypsithermal (Fig. 3).

For both of these, shifts in the Southern Westerlies may have been an important forcing mechanism, possibly superimposed on slower insolation changes. Notably, during the mid-Holocene the marine and terrestrial proxies do not all agree. Most terrestrial proxies show warming in this period, whereas the Palmer Deep-a key offshore record west of the Antarctic Peninsula-shows relatively cool conditions. There are various possible explanations, including differences in seasonal insolation forcing (e.g., Renssen et al., 2005) or albedo feedbacks that served to amplify changes in certain proxies close to the coast (Bentley et al., in press).

The differences among proxy records carry an important implication: it is unwise to rely on any individual type of paleoclimate record, even to identify when past warm periods occurred. Two other warm periods are less well recorded in those

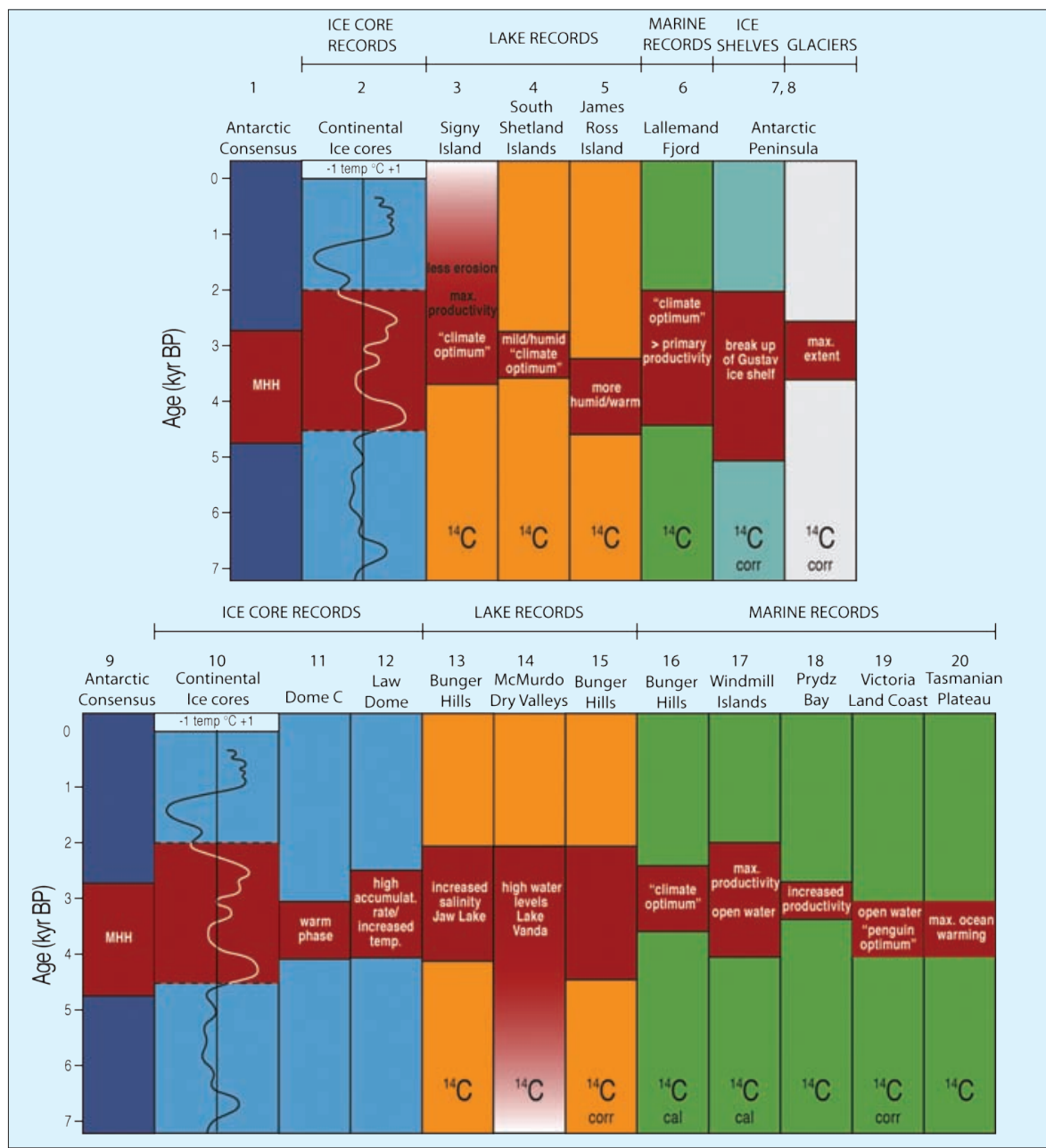

Figure 3: Summary of selected records showing the Mid-Holocene Hypsithermal (MHH). Top panel: Maritime Antarctic and Antarctic Peninsula. Bottom panel: Continental Antarctica. Red shading indicates periods of relative warmth inferred from proxy records. ${ }^{14} \mathrm{C}$ and ${ }^{14} \mathrm{C}$ corr. differentiates whether uncorrected or corrected radiocarbon dates were applied in the original studies. The 'Antarctic consensus' is based on some of the best radiocarbon dated records, which place the hypsithermal between either 4 and $2.7^{14} \mathrm{C} \mathrm{kyr} B P(4.5$ and $2.8 \mathrm{cal}$. kyr BP) in the Antarctic Peninsula region (Björck et al., 1991) or 3.8 and 1.4 cal. kyr BP in the maritime Antarctic (Jones et al., 2000; Hodgson and Convey, 2005). Continental ice core plots are measured as average temperature curve from 6 ice cores. Temperature is expressed as the departure from the mean of the past $5 \mathrm{kyr}$. Modified from Hodgson et al., 2004. Numbers above plots match references listed online at www.pages-igbp.org/products/newsletters/ref2009_1.html

proxies studied and require greater focus, namely the Medieval Warm Period and the Recent Rapid Regional Warming (robustly known from instrumental records). This exercise has also exposed other key gaps in knowledge. There is a need for a regional ice core spanning the Holocene (in this case we are looking forward to the first results from James Ross Island, drilled in 2008) and for better understanding of the Holocene history of oceanic water masses such as Circumpolar Deep Water, as well as a need to extend the network of marine and terrestrial (lake) geological records.

\section{Future priorities}

The establishment of improved linkages between glacial geologists, paleoclimatologists and modelers will aid our understanding of ice sheet history and past patterns of climate change in all regions of Antarctica. In turn, this will inform a new generation of models that are regionally sensitive, and stimulate field programs to collect data to constrain such models. Some such models already exist: e.g., the model simulations of Renssen et al. (2005) have already been used to explain some of the contrasts between marine and terrestrial records during the mid-Holocene warm period in the Antarctic Peninsula region (Bentley et al., in press).

\section{References}

Bentley, M.J., et al., in press: Mechanisms of Holocene palaeoenvironmental change in the Antarctic Peninsula region, The Holocene.

Graham, A.G.C., Fretwell, P.T., Larter, R.D., Hodgson, D.A., Wilson, C.K. Tate, A.J. and Morris,P., 2008: A new bathymetric compilation highlighting extensive paleo-ice sheet drainage on the continental shelf, South Georgia, sub-Antarctica, Geochemistry Geophysics Geosystems, 9(7): doi:10.1029/2008GC001993.

Hodgson, D.A., Doran, P.T., Roberts, D. and McMinn, A., 2004: Paleolimnological studies from the Antarctic and sub-Antarctic islands, In: Pienitz, R., et al., (Eds), Developments in paleoenvironmental research volume 8, Long-term environmental change in Arctic and Antarctic Lakes, Springer, 419-74.

Renssen, H., Goosse, H., Fichefet, T., Masson-Delmotte, V. and Koç, N., 2005: Holocene climate evolution in the high-latitude Southern Hemisphere simulated by a coupled atmospheric-sea-iceocean-vegetation model, The Holocene, 15: 951-64.

Stone, J.0., Balco, G.A., Sugden, D.E., Caffee, M.W., Sass, L.C., Cowdery, S.G. and Siddoway, C., 2003: Holocene Deglaciation of Marie Byrd Land, West Antarctica, Science, 299: 99-102. doi: 10.1126/ science. 1077998 .

For full references please consult:

www.pages-igbp.org/products/newsletters/ref2009_1.html 